\title{
Pornographication: A discourse for all seasons
}

As part of research for a teaching session I entered the words pornographication and pornification into Google; the first more unwieldy term collected 7450 hits, while the second was more popular with 28,700 hits. Always one for a bit of procrastination, I started to work my way through some of those hits. I was particularly interested by those which proclaimed

The nation has been pornified. ${ }^{1}$

The pornification of teen life ${ }^{2}$

The pornification of politics ${ }^{3}$

The pornification of Britain ${ }^{4}$

The pornographication of society ${ }^{5}$

Pornographication: Why men don't respect women ${ }^{6}$

As pornography continues to become more prominent and pornographic imagery becomes more 'mainstreamed' we become accustomed to living in a pornified world in which it is acceptable that women and girls can be bought and sold. ${ }^{7}$

Each of these identified what their authors understood to be a remarkable new phenomenon, unstoppable and unregulated, indicative of a general malaise in society and with unforeseen consequences for our emotional and sexual lives. Of the links I visited, many were Christian in origin; others were blogs with unclear politics, some left-leaning, others right-wing, feminist, activist; there were some online issues of newspapers and magazines; and others involved policy documents and submissions to government agencies. Amongst the cacophony of concern were listings for a number of academic books including Paasonen et al.'s (2007: 2) Pornification: Sex and Sexuality in Media Culture,
1. http://blogs. psychologytoday.com/ blog/genius-andmadness/200903/ the-pornificationhumanconsciousness

2. http://contexts.org/ socimages $/ 2008$ /04/09/thepornification-ofteen-life/

3. http://www.realclearpolitics. com/articles/2007/07/ youtube_the_pornification_of_p.html

4. hhtp://www.geoffbarton.co.uk/files/ features/ Pornification. doc

5. http://www.failedstate co.uk/2007/03/ pornographicationof-society.html 
6. www.rockisu.com/ media/porngraphication1.pdf

7. http://www.catwa.org. $\mathrm{au} / \mathrm{q}=$ pornography an erudite and careful collection that considers the intertwining processes of technological development, shifts in modes of representation and the cultural visibility of cultures of sexuality'. Other titles included Pamela Paul's Pornified and Ariel Levy's Female Chauvinist Pigs, neither of which is so careful to lay out the terrain on which their arguments are based.

Desirous of putting the couple of hours of googling to good use, I want to problematize the uses of 'pornographication' and 'pornification' in this commentary. My central claim here is that, notwithstanding Paasonen et al.'s careful dissection of the term 'pornification', its usefulness may well have been exceeded. Further, I argue that the terms have been so widely taken up as descriptions and explanations of cultural shifts and worrying experiences, that they obscure the specific histories and politics of both the cultural artefacts under examination and those who are doing the examination. The claims of 'pornographication' and 'pornification' are already so saturated in the languages and references of concern and regulation that they restrict the range of possible explanations that can be admitted.

Etymologies of any conceptual term, especially one as recent as pornographication, can be difficult and we are also presented with the difficulty of differentiating between it and another recent term, 'sexualization of culture', which has also found its way into 'common-sense' discourse. Feona Attwood (2006: 82) has described sexualization as the 'widespread fascination with sex and the sexually explicit in print and broadcast media ... sex is becoming more and more visible, and more explicit' and, as she goes on to argue, more accessible via the emergence of new technologies. 'Pornographication' and 'pornification' have been conceived as part of this broader expansion of the forms of 'sexual discourse, economic and cultural exchange and sexual practice' (Attwood 2006: 82) and their first usage seems to have occurred in the work of Brian McNair where it performed a particular function. McNair traced pornographication as a result of

the collision of ideological shifts caused by decades of sex-political struggle with a postmodern intellectual climate in which the meaning of the pornographic can be remade, and its perverse pleasures recognised.

(McNair 2002: 81)

Thus he saw a fascination with sex and sexuality as a potentially transgressive force against the traditional boundaries of public and private, an expansion of the sexual sphere, a 'democratization of desire', which through the rise of new technologies gave access to the means of sexual expression and the pluralizing of sexual cultures to include those (e.g. gays, lesbians, trans-people and other so-called 'perverts') who had been specifically excluded from sexual self-definition. Unfortunately, for his more positive analysis, the conceptual term has been taken up by pessimistic authors such as Levy and Paul, who have stripped it of any radical potential and reworked it employing all the condemnatory potential of the associations with pornography. Levy coined her own term for the processes of pornographication 'raunch':

I would turn on the television and find strippers in panties explaining how best to lap dance a man to orgasm. I would flip the channel and see babes in tight, tiny uniforms bouncing up and down on trampolines. Britney 
Spears was becoming increasingly popular and increasingly unclothed, and her undulating body ultimately became so familiar to me I felt like we used to go out.

(Levy 2005: 1)

Paul (2005: 1) bemoaned the effects that 'pornified' culture was having on 'our lives, our relationships and our families'. It is this particular view that pornographication is a potent cause in the coarsening and commercialization of sexual practices that has acquired the ascendancy. For example, in a recent article in the popular tabloid The Sun, Emma Cox joined the barrage of complaints about pornified popular culture in an article headlined 'Pornification of Our Kids' and claimed:

Youngsters' minds are being turned after exposure to a disturbing amount of indecent and even hardcore imagery which encourages them to copy what they have seen, says a shocking new study.

(Cox 2009)

Backed up by various statistics sourced from the Channel 4 programme Sex Education versus Pornography, ${ }^{8}$ the article went on to decry teenagers' practices of 'unsafe sex, boob jobs and Hollywood waxes', as well as the 'girls as young as 14 and 15 stripping on webcams and sending pictures to boyfriends - who think writhing in front of a lens is the norm', all part of the 'twisted and unnatural views of sex' teenagers are gleaning from pornography.

Pornographication/pornification has no very precise meaning; they are a matter of social and cultural perception. The same questions asked of obscenity, pornography, erotica - what are the boundaries of the term, what is included and excluded and why, how are its boundaries maintained - need to be asked of 'pornographication'. How is this term deployed and to what ends? Of course, pornography has long been wielded as a means of expressing dismay at many unconnected behaviours, as Gayle Rubin observed:

Due to the stigma historically associated with sexually explicit materials, we already use the words 'obscene' and 'pornographic' to express many kinds of intense revulsion. For example, war may be 'obscene' and Reagan's policies 'pornographic'. However, neither is customarily found in adult bookstores.

(Rubin 1993: 37)

In an account such as Cox's, which draws on the 'obviousness' that there is a problem whose cause can be identified in the expansion of a singular cultural form, where practices of bodily display are conflated with beauty practices and risky sexual behaviour, it is tempting to bring 'pornographication' into play. The catch-all term seems to explain everything, but in its very comfort lies its superficiality.

One of my central worries is that pornographication is a term that in its current deployment has no intellectual usefulness, that even as it claims to trace patterns, processes and trajectories, it actually obscures them in order to make discursive assertions of effects and consequences which must be acknowledged as 'obvious' - all right-thinking individuals must recognize the harms
8. A week-long series of programmes that sought to examine the ways in which teenagers engage with pornography and how that information competes with sex education, screened during March 2009. 
of 'pornographication'. Those who use the term pornographication do so precisely so that they can avoid any of the particularities of sexually explicit media. The obviousness of the term should alert us to the ways in which pornographication is not something that can be 'discovered', 'uncovered' and 'challenged', but instead it is a means of ensuring that behaviours, practices and actions can be labeled and assessed as problematic without addressing specific issues relating to their history, production and consumption; and that can suggest 'solutions' which are both intensely political and denuded of real politics at the same time. As Walter Kendrick observed in his study The Secret Museum, the identification of a problem with its attendant victims, villains and experts makes possible the categorization and containment of 'pornography' and creates an 'imaginary scenario of danger and rescue' (Kendrick 1997: xiii).

Pornification or pornographication need to be interrogated as conceptual terms when they are so easily adopted by such disparate commentators as academic and popular feminists, politician Jacqui Smith, neo-con blogger Crunchy Con, practitioners in psychiatry and psychology, the police, religious groups, right-wing groups, the tabloids and the broadsheet press, documentary makers, teachers as well as academics in film, media and cultural studies.

Can there really be a descriptive term that so adequately meets all their needs? Pornographication is a problem, not a description. When pornographication links together Bratz dolls, pornstar t-shirts, playboy key rings, pole dancing, lads mags, push-up bras for teenagers, breast enlargement, breast reduction, vaginaplasty, Viagra, the sexual self-representations of sexblogs, sexting, Beautiful Agony and SuicideGirls, anime and hentai, burlesque, Cosmopolitan magazine, a photograph of Miley Cyrus in Vanity Fair and the photographs from Abu Ghraib, Max Hardcore's prolific output, TV programmes like Girls Gone Wild, Sex and the City and Porn: A Family Business, we should be ringing alarm bells at the conflation and supposed obviousness of the connections, not wringing our hands and looking to government for solutions. As Hall et al. eloquently argued in another context, in Policing the Crisis:

The fact is that the things being used here as a peg to hang a thesis on are not 'connected' in any tangible or concrete way at all, except rhetorically, ideologically. They may be part of the same nightmare: they are only in the most metaphorical manner part of the same historical phenomenon. It is not the similarity of the events, but the similarity of the underlying sense of panic in the mind of the beholder which provides the real connection.

(Hall et al. 1978: 300)

What does it mean to say that these different phenomena share the sexual themes of pornography? Too often this is linked to the various declamations of the objectification of women, unreal expectations of sexual availability and prowess, a singular focus on genitalia and an emphasis on sex as just a fun activity. We should be clear then that most uses of pornification and pornographication are condemnatory. The attendant claims that such phenomena 'normalize' pornography is insufficient reason to lump them together. It is not obvious to me what this notion of normalization means, but that it is the pointits proponents offer it as something so obvious it needs no further explanation.

For its proponents, the pornographication of the mainstream is not just a cause for concern, it is also a cause of bad behaviours. For example, preacher Charles Colson claimed that soldiers at Abu Ghraib were corrupted by 'a steady 
diet of MTV and pornography' (quoted in Rich 2004) and Mary Ann Tetreault observes of the images recording the abuse that

I would call these photographs pornographic, if we define pornography as a record of the violation of a subject's physical and psychic integrity ... many Abu Ghraib images also are pornographic in the conventional sense ... These photos ... are like stills from snuff films.

(Tetreault 2006) ${ }^{9}$

These and other claims about 'torture porn' draw on a particular notion of the pornographic. I'm not arguing here that the torture meted out in the prison was not disgusting - it certainly was - but was it pornographic? I resist that label for the following reasons - to call this pornographic is to obscure the very particular ways in which the state was not just involved but instituted the actions within the prison; calling this pornography reduces the very real harms done to prisoners by US soldiers to individuals acting under the supposed influence of sexually explicit representations.

The US Army legitimized state action in Iraq, while the power and authority invested in the military machine licensed the perpetrators of the torture. Furthermore, the delineation of the images and their circulation as 'pornography' insists on an understanding of the ways in which those images were consumed - the presumption is that any viewer encountered them as sexual images first and foremost. There may be many ways of engaging with these images but surely the most prominent possible engagement indicates the redundancy of the use of the term pornography - many viewers of these images understood them as confirmation of the skewed politics, ethics and morals of the so-called War on Terror. This was not pornography, it was state-sanctioned torture and it needs to be understood in all its historical specificity as such; labeling it pornography disguises the politics at the heart of Abu Ghraib.

The problem with pornographication is that it is a conceptual sledgehammer which draws very particularly from earlier arguments proposed by both moralists and feminists such as Dworkin - that so long as a cultural item 'smells' like porn then that's what it is. There are of course the particular difficulties of defining pornography but such definitions are hardly helped by the incorporation of Bratz dolls as components of the 'industry'. How then do we address the specificities of the production, consumption and textual forms of those materials which actually do include purposively sexually explicit content and graphic representations of sexual activity and which are subject to a range of regulatory controls not in operation elsewhere in the mainstream?

Clearly, for individual theorists of the pornification of culture, this is a strategic move; it means there is no need to actually engage with either production or consumption, but one can instead point to the commodification of sexual pleasure and rest assured that the generalized suspicion of commodity capitalism which characterizes western intellectual thought will do the rest of the work. Hence, adopting terms like 'commercial sex ${ }^{\prime 10}$ to supposedly differentiate between forms of activity makes clear the problem element. Though why sex should not be commercialized when every other human endeavour is commercialized is unclear - just like any other academic, my life is entirely commercialized, from the foods I ingest, the clothes that keep me warm, to the music, books and films which entertain me; there is no pleasure, no emotion, no physical sensation that is not commercialized, and while I might want to
9. Tetreault goes on to condemn the government's trivialization of the issues in order to scapegoat individuals rather than policy but her arguments about the influence of porn remain problematic.

10. I distinguish here between the work of academics such as Laura Agustin (2007) who uses the term 'commercial sex' to encompass a range of activities involving the exchange of services for money and those who use the conceptual category 'commercial sex' as a means of insisting on the links between pornography and prostitution. The idea of the continuum is another rhetorical strategy, dependent upon ideological construction of the prostitute as a woman who needs saving. This definitional project also obscures the ways in which power and authority are fully implicated in the problems - of stigmatization, harassment and blame - endured by sex workers. 
claim that my sexual self is some sort of authentic real me, the idea that this can be separated out from all the other ways in which I exist in this world, to be unsullied by commercialism, is ridiculous and simply a means of replacing analysis with condemnation. For those of us who would seek to examine sexually explicit materials in all their forms and contexts, who would wish to explore the ways in which sex has become the big story, we will need to challenge the terminology which characterizes much of public discourse.

\section{REFERENCES}

Agustin, Laura (2007), Sex at the Margins: Migration, Labour Markets and the Rescue Industry, London: Zed Books.

Attwood, Feona (2006), 'Sexed Up: Theorizing the Sexualization of Culture', Sexualities, 9.

Cox, Emma (2009), 'Pornification of our kids', The Sun, http://www.thesun.co.uk/ sol/homepage/features/article2348839.ece. Accessed 15 May 2009.

Hall et al. (1978), Policing the Crisis: Mugging, the State and Law and Order, Basingstoke: Macmillan.

Kendrick, Walter (1997), The Secret Museum: Pornography in Modern Culture, New York: Viking.

Levy, Ariel (2005), Female Chauvinist Pigs: Women and the Rise of Raunch Culture, New York: Free Press.

McNair, Brian (2002), Striptease Culture: Sex, Media and the Democratization of Desire, London: Routledge.

Paasonen, Susanna, Nikunen, K. and Saarenmaa, L. (eds) (2007), Pornification: Sex and Sexuality in Media Culture, Oxford: Berg.

Paul, Pamela (2005), Pornified: How Pornography Is Transforming Our Lives, Our Relationships and Our Families, New York: Times Books.

Rich, Frank (2004), 'It was the porn that made them do it', The New York Times, 30 May.

Rubin, Gayle (1993), 'Misguided, Dangerous and Wrong: An Analysis of AntiPornography Politics', in A. Assister and A. Carol (eds), Bad Girls and Dirty Pictures: The Challenge to Reclaim Feminism, London: Pluto Press, pp. 18-40.

Tetreault, Mary Ann (2006), 'The Sexual Politics of Abu Ghraib: Hegemony, Spectacle and the Global War on Terror, NWSA Journal, 18.

\section{CONTRIBUTOR DETAILS}

Clarissa Smith is the author of One for the Girls! The Pleasures and Practices of Reading Women's Porn (2007, Bristol: Intellect). She teaches at the University of Sunderland, where she is the Programme Leader for the MA Film \& Cultural Studies, and MA Media \& Cultural Studies. She is also the Reviews Editor for Participations: http://www.participations.org.

Contact: Centre for Research in Media \& Cultural Studies, University of Sunderland, David Puttnam Media Centre, St Peters Campus, Sunderland, SR6 ODD, UK.

E-mail: clarissa.smith@sunderland.ac.uk 
Copyright of International Journal of Media \& Cultural Politics is the property of Intellect Ltd. and its content may not be copied or emailed to multiple sites or posted to a listserv without the copyright holder's express written permission. However, users may print, download, or email articles for individual use. 